\title{
H19 in Endocrine System Tumours
}

\author{
MAŁGORZATA ROLLA, ALEKSANDRA JAWIARCZYK-PRZYBYŁOWSKA, \\ KATARZYNA KOLAČKOV and MAREK BOLANOWSKI
}

Department of Endocrinology, Diabetes and Isotope Therapy, Wroclaw Medical University, Wroclaw, Poland

\begin{abstract}
Long non-coding RNAs (IncRNAs) are over 200 nucleotides long recently discovered RNA molecules that are not involved in the translation process. Accumulating evidence shows that H19 IncRNA is an important regulator of gene expression and its altered expression contributes to carcinogenesis. The aim of this review was to reveal current knowledge about H19 IncRNA and its impact on tumours of the endocrine system. We present findings about H19 altered regulation and its association with tumorigenesis, cancer progression and differentiation, and its potential use in diagnostics, prognostics and therapy. The mechanism and molecular pathways involved in these processes are discussed.
\end{abstract}

Non-coding RNAs (ncRNAs) are recently discovered molecules, which do not participate in the translation process and do not have their own protein product (1-3). Approximately $80 \%$ of human genome is transcribed into functional RNA, but less than $2 \%$ is involved in translation and has protein-coding capacity (4). Therefore, ncRNAs are an abundant group of transcripts that can be divided according to their length or function. According to their length, we can distinguish them into small ncRNAs (less than 200 nucleotides long) and long noncoding RNAs (lncRNAs) (1-3). ncRNAs are divided according to their function into housekeeping ncRNAs and regulatory ncRNAs (2, 5). Ribosomal (r-), transfer (t-), small nuclear (sn) and small nucleolar (sno-) ncRNAs are housekeeping, whereas micro (mi-), small interfering (si-), piwi-interacting (pi-) and

This article is freely accessible online.

Correspondence to: Małgorzata Rolla, Department of This article is freely accessible online.

Endocrinology, Diabetes and Isotope Therapy, Wroclaw Medical University, Wybrzeże L. Pasteura 4, 50-367, Wrocław, Poland. e-mail: malgorzata.rolla@student.umed.wroc.pl

Key Words: H19, IncRNA, pituitary adenoma, thyroid cancer, adrenal tumour, neuroendocrine tumour, review. long non-coding (lnc-) ncRNAs are regulatory $(2,5)$. Up to November 2020, over 260,000 types of human lncRNAs had been identified (6). LncRNAs can be located in the nucleus or cytoplasm (5). Their function is still poorly understood, but their biological roles seem to be more crucial than it was initially hypothesized $(1,3,5)$. Accumulating evidence shows that lncRNAs are important regulators of gene expression (3). They play roles in regulation and modification of transcription, posttranscription and epigenetic processes $(2,3)$. Evidence has revealed that they are involved in the development of diabetes $(7,8)$ and neurological diseases (9-11). Recent studies have shown that aberrant expression of lncRNAs may also contribute to carcinogenesis $(2,3,12,13)$.

\section{H19 RNA}

H19 lncRNA was the first discovered lncRNA; it was initially classified as an mRNA with unknown protein product and was extracted from a mouse liver (14). A few years later, Brannan et al. isolated $\mathrm{H} 19$ gene from human tissues and stated that the only final product of $H 19$ gene may be an mRNA transcript, located in the cytoplasm (15). The full length of H19 RNA chain is $2.3 \mathrm{~kb}$ (16). In human, the gene is mapped on chromosome 11p15.5 (17). The expression of H19 is high during embryonic development $(14,18)$, mainly in the endoderm and mesoderm (19), and maximum expression has been observed in the liver, muscles and adrenals $(19,20)$. After birth, it is down-regulated in most tissues, but its expression is still detectable in inter alia, skeletal muscle, myocardium and mammary gland tissues $(19,21)$.

\section{H19 - Contribution to Carcinogenesis}

The linkage between $H 19$ and cancer development was the subject of many studies since the 1990s $(18,22,23)$. Bartolomei et al. first discovered that $\mathrm{H} 19$ is expressed exclusively from the maternal allele, due to the imprinting process (24). Knowledge about the influence of imprinting alterations on carcinogenesis led to search for an association between $H 19$ gene and its 
potential role in cancer development (18). Probable mechanisms are loss of imprinting (LOI) - an epigenetic event resulting in biallelic gene expression, and changes in the methylation pattern of promoters sequences, which regulate the levels of gene expression (25). It has been proposed that these two mechanisms are strongly related, due to the involvement of methylation in the inactivation of the paternal allele (26). It is important to note that $H 19$ and IGF2 genes are commonly imprinted interdependently due to their close location on 11p15.5 (27). Association between LOI of $\mathrm{H} 19$ gene and tumorigenesis was described inter alia, for oesophageal (28), colorectal (28) and lung cancers (29). Additionally, in Wilms' tumour, LOI of IGF2 gene contributes to methylation of $H 19$ promoter, resulting in the down-regulation of H19 expression (30). Nevertheless, LOI does not always directly correspond to a methylation pattern and level of gene expression, as it has been shown by Byun et al. in a study on bladder cancer (25). In contrast to the above studies, Yballe et al. have shown no connection between LOI of H19 gene and the occurrence of breast cancer (31). Similar results were obtained for neuroblastoma by Wada et al. (32). Further studies have been performed on the mechanisms of $H 19$ contribution in carcinogenesis. $H 19$ has been proposed as an oncogene $(33,34)$, tumour suppressor $(35,36)$ or as an oncofoetal RNA, associated with germ cell tumours $(18,19,37)$.

The oncogenic properties of H19 may be due to its increased expression in neoplasm tissues. Over-expression of H19 RNA has been shown to contribute to the carcinogenesis and progression of tumours of the breast $(34,38)$, lung (39, $40)$, oesophagus $(28,41)$, stomach $(42-44)$, colon $(28,45)$, liver $(46)$, pancreas $(47,48)$, kidney $(49)$, bladder $(46,50)$, cervix $(51)$, ovary $(52,53)$, as well as in glioma $(54,55)$, leukaemia (56), oral squamous cell carcinoma (57), cholangiocarcinoma (58), osteosarcoma $(59,60)$ and melanoma (61). On the other hand, in some tumours downregulation of $H 19$ expression was observed [inter alia in Wilms' tumour $(30,62)]$, which means that $H 19$ may be classified also as a tumour suppressor.

The mechanisms through which H19 is involved in the process of cancer development include promotion of gene mutations, cell proliferation, invasion, migration and angiogenesis, immune and pro-apoptotic factors modulation and growth suppressor expression regulation $(63,64)$. Additionally, some studies have shown that H19 RNA functions through sponging mi-RNAs including miR-675 $(45,48)$, miR-107 $(39,40)$, miR-370-3p (65), miR-106a-5p (61), miR-29a (54), miR-29a-3p (49) and miR-138-5p (51).

In recent meta-analyses $(64,66)$ the prognostic and clinicopathological values of $H 19$ in different types of cancers were explored. Both studies demonstrated that high levels of H19 RNA contribute to shorter overall survival and associate with more advanced clinical stage of tumours and lymph node metastasis. Additionally, H19 RNA positively correlates with poor tumour differentiation, earlier distant metastasis (64), as well as with poorer histological tumour grade and disease-free survival (66). Summarizing, H19 RNA has been demonstrated as a potential marker for tumour progression and patient's prognosis.

So far, $\mathrm{H} 19$ has been introduced as an intriguing figure in neoplasms' origin and development. But what is its impact on tumours of the endocrine system?

\section{Pituitary Adenomas}

In the study by Lu et al., significantly higher expression of H19 was observed in aggressive growth hormone-secreting pituitary adenomas compared to non-invasive growth hormone-secreting tumours (67). A similar observation was made for oesophageal cancer (H19 correlated positively with tumours' depth, stage and metastasis) (41), lung cancer (H19 enhanced cell proliferation, migration, and invasion of a cell line) (68), glioblastoma (in cell line and xenograft mouse model, H19 promoted invasion, angiogenesis and tumour growth) (55), cholangiocarcinoma (H19 positively correlated with tumour size, cell migration and invasiveness in tissues and cell lines) (58). Thus, we could hypothesize that in invasive pituitary adenomas $H 19$ might be a potential marker of malignancy and patients' prognosis.

On the other hand, Wu et al. (69) and Zhang et al. (70) observed down-regulation of $H 19$ expression in pituitary tumour tissues and in the plasma obtained from patients with pituitary adenomas in comparison to normal pituitary glands and healthy controls. In in vitro and in vivo models, an increase in cell proliferation after knockdown of H19 gene was observed (69). Furthermore, in mouse models injection of H19 lentivirus led to shrinkage of tumour volumes. H19 expression levels negatively correlated with tumour volumes. Antitumor effects were induced by inhibiting 4E-BP1 phosphorylation in the mTORC1/4E-BP1 pathway. Moreover, in xenograft experiments $H 19$ overexpression was more effective than cabergoline in suppressing tumour growth (69). Additionally, the investigators revealed that cabergoline stimulated H19 expression and H19 and dopamine agonists exerted a synergistic therapeutic effect. These results indicate that increasing $H 19$ expression can be a potential therapy for pituitary adenomas. The mechanism of the synergistic action of H19 and dopamine agonists in prolactinomas was investigated in a recent study by $\mathrm{Wu}$ et al. (71). It was revealed that $H 19$ promotes the effects of dopamine agonists by inhibiting miRNA-93a and stimulating ATG7 expression, and this is another example of $H 19$ action by sponging mi-RNA. H19/miRNA-93a/ATG7 axis was elucidated as a potential target of therapy, especially in drugresistant prolactinomas.

Opposite results regarding the influence of $H 19$ on drug resistance, but also describing $H 19$ impact on ATG7, were demonstrated by Pan et al. (72). In non-small cell lung 
cancer cell lines and xenograft models, they observed that H19 sponges miRNA-615-3p and regulates ATG7 expression, and that this mechanism is probably involved in erlotinib resistance.

\section{Thyroid Cancer}

Ambiguous associations between $H 19$ expression and tumour development have also been illustrated for thyroid cancer. In thyroid cancer samples and cell lines, Liu et al. (73) observed over-expression of H19. H19 enhanced tumour growth by inhibiting apoptosis and promoting progression, migration and invasion. Moreover, the researchers found that $H 19$ affects miR-17-5p and antagonizes its effect on YES1 expression. The association between $\mathrm{H} 19$ and miR-17-5p has also been illustrated in gastric cancer cells (74), whereas a positive correlation between the levels of these two RNA was determined. In that study, H19 was associated with larger tumour size, more advanced TNM stage and lymph node metastases. Corresponding outcomes, but for thyroid cancer, were exemplified in the study by Liu et al. (75). Moreover, higher $H 19$ expression was related with lower 5year survival rate.

The mechanism through which $H 19$ contributes to thyroid cancer development was the subject of the studies of Li et al. (76) and Wang et al. (77). In the Li et al. study (76), H19 was found to function through the PI3K/AKT signalling pathway, which plays an important role in carcinogenesis. Similarly, the association of $H 19$ with PI3K/AKT was illustrated in colorectal cancer cell lines (78) and melanoma (79). An additional finding of Li et al. was over-expression of H19 in thyroid cancer tissues compared to adjacent healthy thyroid tissues (76). Moreover, H19 expression was higher in poorly differentiated thyroid cancer tissues. In an in vitro model, knockdown of $\mathrm{H} 19$ resulted in cancer cell viability inhibition and induction of apoptosis (76).

In contrary, Wang et al. (77) showed that H19 overexpression inhibits viability, migration and invasion and induces tumour cells apoptosis and these effects might be mediated via down-regulating the expression of IRS-I (insulin receptor substrate I). Moreover, IRS-I expression might be induced also by PI3/AKT signalling pathway. The results of Wang et al. suggest that $H 19$ could be potentially used in thyroid cancer treatment.

The H19 effect on the development of specific types of thyroid cancer was the subject of several studies presented below. For papillary thyroid cancer (PTC), higher tissue expression of $H 19$ was observed in the studies of Liang et al. (80) and $\mathrm{Li}$ et al. (81). Different mechanisms were proposed for expounding $H 19$ involvement in PTC development. In the first study, higher expression was positively correlated with mesenchymal phenotype biomarkers (vimentin, ZEB2, Twist, Snail2), which indicates that H19 RNA induces epithelial-mesenchymal transition (EMT) process. EMT has been described to play a critical role in cancer invasiveness and metastasis (82). A similar effect of $H 19$ on EMT was depicted for ovarian (65), oesophageal (41) cancers and cholangiocarcinoma (58). Moreover, in the ovarian cell line, H19 was shown to promote EMT-related activity and contribute to cisplatin resistance (83). Li et al. (81) proposed a mechanism that was related to ER $\beta$ (oestrogen receptor beta). Oestradiol enhanced $H 19$ expression by ER $\beta$ whereas high expression of $H 19$ promoted expression of ER $\beta$ (as a positive feedback). Additionally, $H 19$ acted through miR-3126-5p and this is another example of sponging mi-RNA by $H 19$.

In the study by Liang et al., H19 expression was positively correlated with tumour size and grade, as well as with lymph node metastases (80). The opposite results were obtained by Lan et al. (84). Jiao et al. (85) observed downregulation of $\mathrm{H} 19$ in papillary thyroid cancer tissues compared to paracancerous or benign nodes. Additionally lower expression of $H 19$ coincided with the presence of lymph node metastasis $(84,85)$, as well as with other features of poorer prognosis, such as higher tumour size, more aggressive histological type and poorer diseases-free survival (85).

For minimally invasive follicular thyroid cancer, Dai et al. examined whether $H 19$ could be a marker of distant metastasis and patients' prognosis (86). The study revealed low expression of H19 in cancer tissues and H19 levels were negatively correlated with tumour size, vascular invasion, distant metastasis and poorer overall survival.

Zhang et al. demonstrated that H19 RNA is overexpressed in anaplastic thyroid carcinoma tissues and cell lines (87). Moreover, they showed that reduction of $H 19$ expression can be a potential target of molecular therapy it decreased cell proliferation, migration and invasion in vitro as well as inhibited tumorigenesis and metastasis in vivo.

Alike divergences of $H 19$ expression levels in different types of thyroid cancer samples were observed by Wächter et al. (88). In anaplastic carcinoma, it was upregulated in six cases, down-regulated in two and was similar to healthy thyroid tissue in four. In follicular thyroid cancer, it was down-regulated in five samples and was the same in three cases. In papillary thyroid cancer it was overexpressed in five samples, down-regulated in two and stable in four. Thus, no association was observed between H19 levels and type of thyroid cancer. In summary, in thyroid cancer, H19 was found to act both as an oncogene as well as a suppressor.

\section{Adrenals}

During embryonic and foetal life adrenal expression of $H 19$ is very high $(89,90)$. In adulthood it remains highly expressed - it shows approximately $50 \%$ of the foetal 
expression (91). Gao et al. (92) and Liu et al. (91) showed that in benign adrenal adenomas and hyperplastic adrenals, H19 is expressed at about the same level as in healthy glands. However, similarly to Glover et al. they showed that in adrenocortical carcinomas the expression was reduced and it was significantly lower than in normal adrenals (91-93), whereas in pheochromocytomas the expression was variable, but generally decreased (91). Upon further investigation, Liu et al. showed that H19 expression was also decreased in virilizing adrenal adenomas (94). The proposed mechanism causing the low H19 expression in adrenocortical carcinomas was methylation of the promoter area (92). The degree of methylation of the promoter $\mathrm{CpG}$ regions in patients with adrenocortical cancers and adenomas was the subject of the study of Barreau et al. (95). The characterized cancers had a higher degree of methylation compared to adenomas that corresponded to patients' poorer prognosis. H19 was found to be one of the genes with a hypermethylated promoter region leading to its down-regulation. Moreover, it showed the strongest observed inverse correlation between methylation levels and gene expression in this study, leading to a conclusion that $H 19$ plays a role as a suppressor. A comparable effect of methylation of the H19 promoter on carcinogenesis was shown for bladder cancer (25) and Wilms' tumour (30). Additionally, Creemers et al. (96) proposed that the methylation status of IGF2 and H19 regulatory regions as useful markers in distinguishing malignant adrenocortical carcinomas from benign adenomas. Thus, we could conclude that H19 expression levels and the methylation pattern of its regulatory regions could be promising tools in the diagnosis of adrenal tumours.

In addition, the various degrees of H19 promoter methylation in benign ovarian teratomas (97) as well as in different types of germ cell tumours (GCTs) $(98,99)$, illustrated the diversity in origin and processes involved in the development of these neoplasms. Hence, reduced methylation in adrenocortical carcinomas may reflect their primordial features, however, further investigations are needed to evaluate this hypothesis.

\section{Neuroendocrine Tumours}

In the Ji et al. study, aberrant expression of H19 was described as an important element in the development of non-functional pancreatic neuroendocrine neoplasms (pNENs) (100). In primary tumours as well as in metastatic tumours, the levels of $H 19$ expression were variable. However, after evaluation of the association between $H 19$ and tumour's malignancy, the researchers revealed that nonmalignant tumours were characterized by low expression of H19, whereas in malignant pNENs as well as in liver metastases its expression was high. Moreover, high expression correlated positively with tumour size, lymph node and liver metastasis, local invasion, TNM stage, tumour-related death, poorer progression free and overall survival. In the cell line models, the authors showed that silencing H19 led to inhibition of cell proliferation, growth and colony formation and the opposite effects were observed after $H 19$ over-expression. Additionally, overexpression of H19 promoted tumour growth and Ki67 expression in xenograft mouse models. The paper illustrates the possible association between high expression of H19 and VGF (neuropeptide precursor) in neoplasms origin, progression and poorer patient prognosis. Additionally, similarly to Li et al. (76), H19 was shown to be involved in the activation of PI3K/Akt signalling pathway.

Ramnarine et al. showed that H19 was an epigenetic regulator, which contributed to neuroendocrine transdifferentiation (NEtD) - a transformation from prostate cancer to neuroendocrine prostate cancer (101). In addition, high expression of $H 19$ was presented as a practical tool in distinguishing neuroendocrine prostate cancers from prostate adenocarcinomas.

\section{Conclusion}

The aim of this review was to demonstrate the current knowledge about H19 lncRNA and its impact on tumours of the endocrine system. The collected data shed light on the mechanisms and molecular pathways involved in tumorigenesis. H19 was determined to be involved in epigenetic regulation and in miRNA expression control. Moreover, H19 may be a useful factor in differentiating malignancies from benign lesions, as it was demonstrated in aggressive pituitary adenomas (67), adrenocortical carcinomas (91-93) and pNENs (100). Another promising aspect is the down-regulation of $H 19$ as a purpose of targeted therapy, which was illustrated in cell line models of thyroid cancer (76, 87 ) and pNENs (100). On the other hand, upregulation of $H 19$ has also been proposed as a therapeutic tool $(69,70,77)$. In addition, $H 19$ may improve the effects of treatment, like it was illustrated for dopamine agonists in prolactinomas $(69,71)$. Furthermore, abnormal expression of H19 RNA in different types of malignancies makes it a potential biomarker for cancer diagnosis, prognosis and monitoring. In some reports correlation between $H 19$ expression and clinicopathological features was observed, which highlights the prognostic value of this RNA $(75,80,84-86,95)$.

Nevertheless, there are still many questions without unequivocal answers and are subjects for further investigation. First, studies concerning tumours of the endocrine system are limited. Particularly, there is a lack of studies exemplifying a connection between H19 and parathyroid tumours. Additionally, only few studies concerned the potential association between H19 and hormonal function of tumours. Second, there are 
contradictory reports regarding H19 expression in most of the described pathologies. Similarly, to outcomes obtained for other neoplasms, opposite effects of $H 19$ on tumorigenesis in endocrine gland tumours were demonstrated. H19 was proposed to act as an oncogene as well as a suppressor. Currently, the possibility to use its levels as a simple tumour marker is limited. In addition, most presented results were obtained using cancer cell lines and xenograft mouse models. Further investigations on human tumour tissues and plasma concentrations are needed. Finally, the samples of the groups were small in some studies, sometimes due to the rare occurrence of the specific pathology. Therefore, studies with larger sample size are necessary.

In conclusion, $H 19$ is a novel and intriguing factor, which may allow elucidation of processes involved in carcinogenesis and tumour progression. Nevertheless, further investigation of its biological role in endocrine system tumours are still needed.

\section{Conflicts of Interest}

The Authors declare that the research was conducted in the absence of any commercial or financial relationships that could be construed as a potential conflict of interest.

\section{Authors' Contributions}

MR, AJP and MB contributed to the article's conception and design. MR, AJP and KK collected the literature sources. The first draft of the manuscript was written by MR and corrected by AJP, KK and MB. All Authors contributed to the final version of the manuscript and approved it for publication.

\section{References}

1 Ma L, Bajic VB and Zhang Z: On the classification of long non-coding RNAs. RNA Biol 10: 924-933, 2013. PMID: 23696037. DOI: $10.4161 /$ rna.24604

2 Zhang P, Wu W, Chen Q and Chen M: Non-Coding RNAs and their Integrated Networks. J Integr Bioinform 16: 20190027 , 2019. PMID: 31301674. DOI: 10.1515/jib-2019-0027

3 Shi X, Sun M, Liu H, Yao Y and Song Y: Long non-coding RNAs: a new frontier in the study of human diseases. Cancer Lett 339: 159-166, 2013. PMID: 23791884. DOI: 10.1016/j.canlet.2013.06.013

4 ENCODE Project Consortium: An integrated encyclopedia of DNA elements in the human genome. Nature 489: 57-74, 2012. PMID: 22955616. DOI: 10.1038/nature 11247

5 Ponting CP, Oliver PL and Reik W: Evolution and functions of long noncoding RNAs. Cell 136: 629-641, 2009. PMID: 19239885. DOI: 10.1016/j.cell.2009.02.006

6 Ma L, Cao J, Liu L, Du Q, Li Z, Zou D, Bajic VB and Zhang Z: Lncbook: a curated knowledgebase of human long noncoding RNAs. Nucleic Acids Res 47: D128-D134, 2019. PMID: 30329098. DOI: 10.1093/nar/gky960

7 Mirza AH, Kaur S and Pociot F: Long non-coding RNAs as novel players in $\beta$ cell function and type 1 diabetes. Hum
Genomics 11: 17, 2017. PMID: 28738846. DOI: 10.1186/s40246-017-0113-7

8 Motterle A, Gattesco S, Peyot ML, Esguerra JLS, Gomez-Ruiz A, Laybutt DR, Gilon P, Burdet F, Ibberson M, Eliasson L, Prentki M and Regazzi R: Identification of islet-enriched long non-coding RNAs contributing to $\beta$-cell failure in type 2 diabetes. Mol Metab 6: 1407-1418, 2017. PMID: 29107288. DOI: $10.1016 /$ j.molmet.2017.08.005

9 Idda ML, Munk R, Abdelmohsen $\mathrm{K}$ and Gorospe $\mathrm{M}$ : Noncoding RNAs in Alzheimer's disease. Wiley Interdiscip Rev RNA 9: e1463, 2018. PMID: 29327503. DOI: 10.1002/wrna.1463

10 Luo Q and Chen Y: Long noncoding RNAs and Alzheimer's disease. Clin Interv Aging 11: 867-872, 2016. PMID: 27418812. DOI: $10.2147 /$ CIA.S107037

11 Hashemian F, Ghafouri-Fard S, Arsang-Jang S, Mirzajani S, Fallah H, Mehvari Habibabadi J, Sayad A and Taheri M: Epilepsy is associated with dysregulation of long non-coding RNAs in the peripheral blood. Front Mol Biosci 6: 113, 2019. PMID: 31709263. DOI: 10.3389/fmolb.2019.00113

12 Gibb EA, Brown CJ and Lam WL: The functional role of long non-coding RNA in human carcinomas. Mol Cancer 10: 38, 2011. PMID: 21489289. DOI: 10.1186/1476-4598-10-38

13 Tsai KW, Tsai CY, Chou NH, Wang KC, Kang CH, Li SC, Lao YH and Chang HT: Aberrant DNA hypermethylation silenced lncRNA expression in gastric cancer. Anticancer Res 39: 53815391, 2019. PMID: 31570433. DOI: 10.21873/anticanres.13732

14 Pachnis V, Belayew A and Tilghman SM: Locus unlinked to alpha-fetoprotein under the control of the murine raf and Rif genes. Proc Nadl Acad Sci USA 81: 5523-5527, 1984. PMID: 6206499. DOI: $10.1073 /$ pnas.81.17.5523

15 Brannan CI, Dees EC, Ingram RS and Tilghman SM: The product of the H19 gene may function as an RNA. Mol Cell Biol 10: 2836, 1990. PMID: 1688465. DOI: 10.1128/mcb.10.1.28

16 Gabory A, Ripoche MA, Yoshimizu T and Dandolo L: The H19 gene: regulation and function of a non-coding RNA. Cytogenet Genome Res 113: 188-193, 2006. PMID: 16575179. DOI: 10.1159/000090831

17 Yoshimura H, Matsuda Y, Yamamoto M, Kamiya S and Ishiwata T: Expression and role of long non-coding RNA H19 in carcinogenesis. Front Biosci (Landmark Ed) 23: 614-625, 2018. PMID: 28930564. DOI: $10.2741 / 4608$

18 Ariel I, Ayesh S, Perlman E, Pizov G, Tanos V, Schneider T, Erdmann V, Podeh D, Komitowski D, Quasem A, de Groot N and Hochberg A: The product of the imprinted H19 gene is an oncofetal RNA. Mol Pathol 50: 34-44, 1997. PMID: 9208812. DOI: $10.1136 / \mathrm{mp} .50 .1 .34$

19 Poirier F, Chan CT, Timmons PM, Robertson EJ, Evans MJ and Rigby PW: The murine $\mathrm{H} 19$ gene is activated during embryonic stem cell differentiation in vitro and at the time of implantation in the developing embryo. Development 113: 1105-1114, 1991. PMID: 1811930.

20 Goshen R, Rachmilewitz J, Schneider T, De-Groot N, Ariel I, Palti $\mathrm{Z}$ and Hochberg AA: The expression of the H-19 and IGF2 genes during human embryogenesis and placental development. Mol Reprod Dev 34: 374-379, 1993. PMID: 7682421. DOI: $10.1002 / \mathrm{mrd} .1080340405$

21 Dugimont T, Curgy JJ, Wernert N, Delobelle A, Raes MB, Joubel A, Stehelin D and Coll J: The H19 gene is expressed within both epithelial and stromal components of human 
invasive adenocarcinomas. Biol Cell 85: 117-124, 1995. PMID: 8785513. DOI: $10.1016 / 0248-4900(96) 85272-5$

22 Biran H, Ariel I, de Groot N, Shani A and Hochberg A: Human imprinted genes as oncodevelopmental markers. Tumour Biol 15: 123-134, 1994. PMID: 8073225. DOI: 10.1159/000217882

23 Ariel I, Lustig O, Schneider T, Pizov G, Sappir M, De-Groot N and Hochberg A: The imprinted $\mathrm{H} 19$ gene as a tumor marker in bladder carcinoma. Urology 45: 335-338, 1995. PMID: 7855987. DOI: $10.1016 / 0090-4295(95) 80030-1$

24 Bartolomei MS, Zemel S and Tilghman SM: Parental imprinting of the mouse H19 gene. Nature 351: 153-155, 1991. PMID: 1709450. DOI: 10.1038/351153a0

25 Byun HM, Wong HL, Birnstein EA, Wolff EM, Liang G and Yang AS: Examination of IGF2 and H19 loss of imprinting in bladder cancer. Cancer Res 67: 10753-10758, 2007. PMID: 18006818. DOI: 10.1158/0008-5472.CAN-07-0329

$26 \mathrm{Li} \mathrm{E}$, Beard C and Jaenisch R: Role for DNA methylation in genomic imprinting. Nature 366: 362-365, 1993. PMID: 8247133. DOI: $10.1038 / 366362 \mathrm{a} 0$

27 Thorvaldsen JL, Duran KL and Bartolomei MS: Deletion of the H19 differentially methylated domain results in loss of imprinted expression of H19 and Igf2. Genes Dev 12: 3693 3702, 1998. PMID: 9851976. DOI: 10.1101/gad.12.23.3693

28 Hibi K, Nakamura H, Hirai A, Fujikake Y, Kasai Y, Akiyama $\mathrm{S}$, Ito $\mathrm{K}$ and Takagi H: Loss of H19 imprinting in esophageal cancer. Cancer Res 56: 480-482, 1996. PMID: 8564957.

29 Kondo M, Suzuki H, Ueda R, Osada H, Takagi K and Takahashi T: Frequent loss of imprinting of the H19 gene is often associated with its overexpression in human lung cancers. Oncogene 10: 1193-1198, 1995. PMID: 7700644.

30 Steenman MJ, Rainier S, Dobry CJ, Grundy P, Horon IL and Feinberg AP: Loss of imprinting of IGF2 is linked to reduced expression and abnormal methylation of H19 in Wilms' tumour. Nat Genet 7: 433-439, 1994. PMID: 7920665. DOI: 10.1038/ ng0794-433

31 Yballe $\mathrm{CM}, \mathrm{Vu} \mathrm{TH}$ and Hoffman AR: Imprinting and expression of insulin-like growth factor-II and H19 in normal breast tissue and breast tumor. J Clin Endocrinol Metab 81: 1607-1612, 1996. PMID: 8636375. DOI: 10.1210/jcem. 81.4.8636375

32 Wada M, Seeger RC, Mizoguchi H and Koeffler HP: Maintenance of normal imprinting of $\mathrm{H} 19$ and IGF2 genes in neuroblastoma. Cancer Res 55: 3386-3388, 1995. PMID: 7614476.

33 Vernucci M, Cerrato F, Besnard N, Casola S, Pedone P V, Bruni $\mathrm{CB}$ and Riccio A: The $\mathrm{H} 19$ endodermal enhancer is required for Igf2 activation and tumor formation in experimental liver carcinogenesis. Oncogene 19: 6376-6385, 2000. PMID: 11175353. DOI: $10.1038 /$ sj.onc. 1204024

34 Berteaux N, Lottin S, Monté D, Pinte S, Quatannens B, Coll J, Hondermarck H, Curgy JJ, Dugimont T and Adriaenssens E: H19 mRNA-like noncoding RNA promotes breast cancer cell proliferation through positive control by E2F1. J Biol Chem 280: 29625-29636, 2005. PMID: 15985428. DOI: 10.1074/jbc.M504033200

35 Moulton T, Crenshaw T, Hao Y, Moosikasuwan J, Lin N, Dembitzer F, Hensle T, Weiss L, McMorrow L, Loew T, Kraus W, Gerald W and Tycko B: Epigenetic lesions at the H19 locus in Wilms' tumour patients. Nat Genet 7: 440-447, 1994. PMID: 7920666. DOI: $10.1038 /$ ng0794-440
36 Hao Y, Crenshaw T, Moulton T, Newcomb E and Tycko B: Tumour-suppressor activity of H19 RNA. Nature 365: 764-767, 1993. PMID: 7692308. DOI: 10.1038/365764a0

37 Verkerk AJ, Ariel I, Dekker MC, Schneider T, van Gurp RJ, de Groot N, Gillis AJ, Oosterhuis JW, Hochberg AA and Looijenga LH: Unique expression patterns of H19 in human testicular cancers of different etiology. Oncogene 14: 95-107, 1997. PMID: 9010236. DOI: 10.1038/sj.onc.1200802

38 Adriaenssens E, Dumont L, Lottin S, Bolle D, Leprêtre A, Delobelle A, Bouali F, Dugimont T, Coll J and Curgy JJ: H19 overexpression in breast adenocarcinoma stromal cells is associated with tumor values and steroid receptor status but independent of p53 and Ki-67 expression. Am J Pathol 153: 1597-1607, 1998. PMID: 9811352. DOI: 10.1016/S00029440(10)65748-3

39 Qian B, Wang DM, Gu XS, Zhou K, Wu J, Zhang CY and He XY: LncRNA H19 serves as a ceRNA and participates in nonsmall cell lung cancer development by regulating microRNA107. Eur Rev Med Pharmacol Sci 22: 5946-5953, 2018. PMID: 30280776. DOI: 10.26355/eurrev_201809_15925

40 Cui J, Mo J, Luo M, Yu Q, Zhou S, Li T, Zhang Y and Luo W: c-Myc-activated long non-coding RNA H19 downregulates miR-107 and promotes cell cycle progression of non-small cell lung cancer. Int J Clin Exp Pathol 8: 12400-12409, 2015. PMID: 26722426.

41 Huang C, Cao L, Qiu L, Dai X, Ma L, Zhou Y, Li H, Gao M, Li W, Zhang Q, Han K and Lv H: Upregulation of H19 promotes invasion and induces epithelial-to-mesenchymal transition in esophageal cancer. Oncol Lett 10: 291-296, 2015. PMID: 26171017. DOI: 10.3892/ol.2015.3165

42 Song H, Sun W, Ye G, Ding X, Liu Z, Zhang S, Xia T, Xiao B, $\mathrm{Xi} \mathrm{Y}$ and Guo J: Long non-coding RNA expression profile in human gastric cancer and its clinical significances. J Transl Med 11: 225, 2013. PMID: 24063685. DOI: 10.1186/14795876-11-225

43 Li H, Yu B, Li J, Su L, Yan M, Zhu Z and Liu B: Overexpression of lncRNA H19 enhances carcinogenesis and metastasis of gastric cancer. Oncotarget 5: 2318-2329, 2014. PMID: 24810858. DOI: 10.18632/oncotarget.1913

44 Arita T, Ichikawa D, Konishi H, Komatsu S, Shiozaki A, Shoda K, Kawaguchi T, Hirajima S, Nagata H, Kubota T, Fujiwara H, Okamoto $\mathrm{K}$ and Otsuji E: Circulating long non-coding RNAs in plasma of patients with gastric cancer. Anticancer Res 33: 3185-3194, 2013. PMID: 23898077.

45 Tsang WP, Ng EK, Ng SS, Jin H, Yu J, Sung JJ and Kwok TT: Oncofetal H19-derived miR-675 regulates tumor suppressor RB in human colorectal cancer. Carcinogenesis 31: 350-358, 2010. PMID: 19926638. DOI: 10.1093/carcin/bgp181

46 Matouk IJ, DeGroot N, Mezan S, Ayesh S, Abu-lail R, Hochberg A and Galun E: The H19 non-coding RNA is essential for human tumor growth. PLoS One 2: e845, 2007. PMID: 17786216. DOI: 10.1371/journal.pone.0000845

47 Ma L, Tian X, Wang F, Zhang Z, Du C, Xie X, Kornmann M and Yang Y: The long noncoding RNA H19 promotes cell proliferation via E2F-1 in pancreatic ductal adenocarcinoma Cancer Biol Ther 17: 1051-1061, 2016. PMID: 27573434. DOI: 10.1080/15384047.2016.1219814

48 Ma L, Tian X, Guo H, Zhang Z, Du C, Wang F, Xie X, Gao H, Zhuang Y, Kornmann M, Gao H and Yang Y: Long noncoding RNA H19 derived miR-675 regulates cell proliferation by 
down-regulating E2F-1 in human pancreatic ductal adenocarcinoma. J Cancer 9: 389-399, 2018. PMID: 29344285. DOI: $10.7150 /$ jca. 21347

49 He H, Wang N, Yi X, Tang C and Wang D: Long non-coding RNA H19 regulates E2F1 expression by competitively sponging endogenous miR-29a-3p in clear cell renal cell carcinoma. Cell Biosci 7: 65, 2017. PMID: 29214011. DOI: 10.1186/s13578017-0193-z

50 Ariel I, Sughayer M, Fellig Y, Pizov G, Ayesh S, Podeh D, Libdeh BA, Levy C, Birman T, Tykocinski ML, de Groot N and Hochberg A: The imprinted H19 gene is a marker of early recurrence in human bladder carcinoma. Mol Pathol 53: 320323, 2000. PMID: 11193051. DOI: 10.1136/mp.53.6.320

$51 \mathrm{Ou} \mathrm{L}$, Wang D, Zhang H, Yu Q and Hua F: Decreased expression of miR-138-5p by lncRNA H19 in cervical cancer promotes tumor proliferation. Oncol Res 26: 401-410, 2018. PMID: 28797320. DOI: 10.3727/096504017X15017209042610

52 Tanos V, Prus D, Ayesh S, Weinstein D, Tykocinski ML, DeGroot N, Hochberg A and Ariel I: Expression of the imprinted H19 oncofetal RNA in epithelial ovarian cancer. Eur J Obstet Gynecol Reprod Biol 85: 7-11, 1999. PMID: 10428315. DOI: 10.1016/S0301-2115(98)00275-9

53 Zhu Z, Song L, He J, Sun Y, Liu X and Zou X: Ectopic expressed long non-coding RNA H19 contributes to malignant cell behavior of ovarian cancer. Int J Clin Exp Pathol 8: 1008210091, 2015. PMID: 26617715.

54 Jia P, Cai H, Liu X, Chen J, Ma J, Wang P, Liu Y, Zheng J and Xue Y: Long non-coding RNA H19 regulates glioma angiogenesis and the biological behavior of glioma-associated endothelial cells by inhibiting microRNA-29a. Cancer Lett 381: 359-369, 2016. PMID: 27543358. DOI: 10.1016/j.canlet.2016.08.009

55 Jiang X, Yan Y, Hu M, Chen X, Wang Y, Dai Y, Wu D, Wang $\mathrm{Y}$, Zhuang $\mathrm{Z}$ and $\mathrm{Xia} \mathrm{H}$ : Increased level of $\mathrm{H} 19$ long noncoding RNA promotes invasion, angiogenesis, and stemness of glioblastoma cells. J Neurosurg 124: 129-136, 2016. PMID: 26274999. DOI: $10.3171 / 2014.12 . J N S 1426$

56 Guo G, Kang Q, Chen Q, Chen Z, Wang J, Tan L and Chen JL: High expression of long non-coding RNA H19 is required for efficient tumorigenesis induced by Bcr-Abl oncogene. FEBS Lett 588: 1780-1786, 2014. PMID: 24685695. DOI: 10.1016/j.febslet.2014.03.038

57 Zhang DM, Lin ZY, Yang ZH, Wang YY, Wan D, Zhong JL, Zhuang PL, Huang ZQ, Zhou B and Chen WL: IncRNA H19 promotes tongue squamous cell carcinoma progression through $\beta$-catenin/GSK3 $\beta /$ EMT signaling via association with EZH2. Am J Transl Res 9: 3474-3486, 2017. PMID: 28804564.

$58 \mathrm{Xu} \mathrm{Y,} \mathrm{Wang} \mathrm{Z,} \mathrm{Jiang} \mathrm{X} \mathrm{and} \mathrm{Cui} \mathrm{Y:} \mathrm{Overexpression} \mathrm{of} \mathrm{long}$ noncoding RNA H19 indicates a poor prognosis for cholangiocarcinoma and promotes cell migration and invasion by affecting epithelial-mesenchymal transition. Biomed Pharmacother 92: 17-23, 2017. PMID: 28528181. DOI: 10.1016/j.biopha.2017.05.061

59 Chan LH, Wang W, Yeung W, Deng Y, Yuan P and Mak KK: Hedgehog signaling induces osteosarcoma development through Yap1 and H19 overexpression. Oncogene 33: 4857-4866, 2014. PMID: 24141783. DOI: 10.1038/onc.2013.433

60 Zhao J and Ma ST: Downregulation of lncRNA H19 inhibits migration and invasion of human osteosarcoma through the NFkB pathway. Mol Med Rep 17: 7388-7394, 2018. PMID: 29568924. DOI: $10.3892 / \mathrm{mmr} .2018 .8746$
61 Luan W, Zhou Z, Ni X, Xia Y, Wang J, Yan Y and Xu B: Long non-coding RNA H19 promotes glucose metabolism and cell growth in malignant melanoma via miR-106a-5p/E2F3 axis. J Cancer Res Clin Oncol 144: 531-542, 2018. PMID: 29350287. DOI: $10.1007 / \mathrm{s} 00432-018-2582-\mathrm{z}$

62 Cui H, Hedborg F, He L, Nordenskjöld A, Sandstedt B, PfeiferOhlsson S and Ohlsson R: Inactivation of H19, an imprinted and putative tumor repressor gene, is a preneoplastic event during Wilms' tumorigenesis. Cancer Res 57: 4469-4473, 1997. PMID: 9377554.

63 Lecerf C, Le Bourhis X and Adriaenssens E: The long noncoding RNA H19: an active player with multiple facets to sustain the hallmarks of cancer. Cell Mol Life Sci 76: 4673-4687, 2019. PMID: 31338555. DOI: 10.1007/s00018-019-03240-z

64 Yu H, Li S, Wu SX, Huang S, Li S and Ye L: The prognostic value of long non-coding RNA H19 in various cancers: A metaanalysis based on 15 studies with 1584 patients and the Cancer Genome Atlas data. Medicine (Baltimore) 99: e18533, 2020. PMID: 31914026. DOI: 10.1097/MD.0000000000018533

65 Li J, Huang YY, Deng XJ, Luo ML, Wang XF, Hu HY, Liu C Di and Zhong M: Long noncoding RNA H19 promotes transforming growth factor- $\beta$-induced epithelial-mesenchymal transition by acting as a competing endogenous RNA of miR370-3p in ovarian cancer cells. Onco Targets Ther 11: 427-440, 2018. PMID: 29403287. DOI: 10.2147/OTT.S149908

66 Liu FT, Pan H, Xia GF, Qiu C and Zhu ZM: Prognostic and clinicopathological significance of long noncoding RNA H19 overexpression in human solid tumors: evidence from a metaanalysis. Oncotarget 7: 83177-83186, 2016. PMID: 27825121. DOI: $10.18632 /$ oncotarget.13076

67 Lu T, Yu C, Ni H, Liang W, Yan H and Jin W: Expression of the long non-coding RNA H19 and MALAT-1 in growth hormone-secreting pituitary adenomas and its relationship to tumor behavior. Int J Dev Neurosci 67: 46-50, 2018. PMID: 29604339. DOI: 10.1016/j.ijdevneu.2018.03.009

68 Liao S, Yu C, Liu H, Zhang C, Li Y and Zhong X: Long noncoding RNA H19 promotes the proliferation and invasion of lung cancer cells and regulates the expression of E-cadherin, $\mathrm{N}$-cadherin, and vimentin. Onco Targets Ther 12: 4099-4107, 2019. PMID: 31190899. DOI: 10.2147/OTT.S185156

69 Wu ZR, Yan L, Liu YT, Cao L, Guo YH, Zhang Y, Yao H, Cai L, Shang HB, Rui WW, Yang G, Zhang XB, Tang H, Wang Y, Huang JY, Wei YX, Zhao WG, Su B and Wu ZB: Inhibition of mTORC1 by lncRNA H19 via disrupting 4E-BP1/Raptor interaction in pituitary tumours. Nat Commun 9: 4624, 2018. PMID: 30397197. DOI: 10.1038/s41467-018-06853-3

70 Zhang Y, Liu YT, Tang H, Xie WQ, Yao H, Gu WT, Zheng YZ, Shang HB, Wang Y, Wei YX, Wu ZR and Wu ZB: Exosometransmitted lncRNA H19 inhibits the growth of pituitary adenoma. J Clin Endocrinol Metab 104: 6345-6356, 2019. PMID: 31369093. DOI: 10.1210/jc.2019-00536

71 Wu ZR, Zheng Y, Xie W, Li Q, Zhang Y, Ren B, Cai L, Cheng Y, Tang $\mathrm{H}$, Su $\mathrm{Z}$ and $\mathrm{Wu} \mathrm{ZB}$ : The long noncoding RNAH19/miRNA-93a/ATG7 axis regulates the sensitivity of pituitary adenomas to dopamine agonists. Mol Cell Endocrinol 518: 111033, 2020. PMID: 32946927. DOI: 10.1016/j.mce.2020.111033

72 Pan $\mathrm{R}$ and Zhou H: Exosomal transfer of lncRNA H19 promotes erlotinib resistance in non-small cell lung cancer via miR-615-3p/ATG7 axis. Cancer Manag Res 12: 4283-4297, 2020. PMID: 32606925. DOI: 10.2147/CMAR.S241095 
73 Liu L, Yang J, Zhu X, Li D, Lv Z and Zhang X: Long noncoding RNA H19 competitively binds miR-17-5p to regulate YES1 expression in thyroid cancer. FEBS J 283: 23262339, 2016. PMID: 27093644. DOI: 10.1111/febs.13741

74 Jia J, Zhang X, Zhan D, Li J, Li Z, Li H and Qian J: LncRNA H19 interacted with miR-130a-3p and miR-17-5p to modify radio-resistance and chemo-sensitivity of cardiac carcinoma cells. Cancer Med 8: 1604-1618, 2019. PMID: 30843379. DOI: $10.1002 / \mathrm{cam} 4.1860$

75 Liu N, Zhou Q, Qi YH, Wang H, Yang L and Fan QY: Effects of long non-coding RNA H19 and microRNA let7a expression on thyroid cancer prognosis. Exp Mol Pathol 103: 71-77, 2017. PMID: 28655518. DOI: 10.1016/j.yexmp.2017.06.004

76 Li X, Li Q, Jin X, Guo H and Li Y: Long non $\square$ coding RNA H19 knockdown inhibits the cell viability and promotes apoptosis of thyroid cancer cells through regulating the PI3K/AKT pathway. Exp Ther Med 18: 1863-1869, 2019. PMID: 31410148. DOI: 10.3892/etm.2019.7720

77 Wang $\mathrm{P}$, Liu G, Xu W, Liu H, Bu Q and Sun D: Long noncoding RNA H19 inhibits cell viability, migration, and invasion via downregulation of IRS-1 in thyroid cancer cells. Technol Cancer Res Treat 16: 1102-1112, 2017. PMID: 29332545. DOI: $10.1177 / 1533034617733904$

78 Zhong ME, Chen Y, Zhang G, Xu L, Ge W and Wu B: LncRNA H19 regulates PI3K-Akt signal pathway by functioning as a ceRNA and predicts poor prognosis in colorectal cancer: integrative analysis of dysregulated ncRNAassociated ceRNA network. Cancer Cell Int 19: 148, 2019. PMID: 31164794. DOI: 10.1186/s12935-019-0866-2

79 Liao Z, Zhao J and Yang Y: Downregulation of lncRNA H19 inhibits the migration and invasion of melanoma cells by inactivating the NF-KB and PI3K/Akt signaling pathways. Mol Med Rep 17: 7313-7318, 2018. PMID: 29568965. DOI: 10.3892/mmr.2018.8782

80 Liang WQ, Zeng D, Chen CF, Sun SM, Lu XF, Peng CY and Lin HY: Long noncoding RNA H19 is a critical oncogenic driver and contributes to epithelial-mesenchymal transition in papillary thyroid carcinoma. Cancer Manag Res 11: 2059-2072, 2019. PMID: 30881130. DOI: 10.2147/CMAR.S195906

81 Li M, Chai HF, Peng F, Meng YT, Zhang LZ, Zhang L, Zou H, Liang QL, Li MM, Mao KG, Sun DX, Tong MY, Deng ZQ, Hou ZJ, Zhao Y, Li J, Wang XC, Lv SS, Zhang QQ, Yu X, Lam EW, Liu Q, Cui XN and Xu J: Estrogen receptor $\beta$ upregulated by IncRNA-H19 to promote cancer stem-like properties in papillary thyroid carcinoma. Cell Death Dis 9: 1120, 2018. PMID: 30389909. DOI: 10.1038/s41419-018-1077-9

$82 \mathrm{Lu} \mathrm{W}$ and Kang Y: Epithelial-mesenchymal plasticity in cancer progression and metastasis. Dev Cell 49: 361-374, 2019. PMID: 31063755. DOI: 10.1016/j.devcel.2019.04.010

$83 \mathrm{Wu}$ Y, Zhou Y, He J, Sun H and Jin Z: Long non-coding RNA H19 mediates ovarian cancer cell cisplatin-resistance and migration during EMT. Int J Clin Exp Pathol 12: 2506-2515, 2019. PMID: 31934077.

84 Lan X, Sun W, Dong W, Wang Z, Zhang T, He L and Zhang H: Downregulation of long noncoding RNA H19 contributes to the proliferation and migration of papillary thyroid carcinoma. Gene 646: 98-105, 2018. PMID: 29287713. DOI: 10.1016/j.gene.2017.12.051

85 Jiao X, Lu J, Huang Y, Zhang J, Zhang H and Zhang K: Long non-coding RNA H19 may be a marker for prediction of prognosis in the follow-up of patients with papillary thyroid cancer. Cancer Biomark 26: 203-207, 2019. PMID: 31403942. DOI: $10.3233 / \mathrm{CBM}-190273$

86 Dai Y, Miao Y, Zhu Q, Gao M and Hao F: Expression of long noncoding RNA H19 predicts distant metastasis in minimally invasive follicular thyroid carcinoma. Bioengineered 10: 383-389, 2019. PMID: 31791180. DOI: 10.1080/21655979.2019.1658489

87 Zhang H, Yu Y, Zhang K, Liu X, Dai Y and Jiao X: Targeted inhibition of long non-coding RNA H19 blocks anaplastic thyroid carcinoma growth and metastasis. Bioengineered 10: 306-315, 2019. PMID: 31299871. DOI: 10.1080/21655979.2019.1642722

88 Wächter S, Damanakis AI, Elxnat M, Roth S, Wunderlich A, Verburg FA, Fellinger SA, Bartsch DK and Di Fazio P: Epigenetic modifications in thyroid cancer cells restore NIS and radio-iodine uptake and promote cell death. J Clin Med 7: 61, 2018. PMID: 29561759. DOI: $10.3390 / \mathrm{jcm} 7040061$

89 Voutilainen R, Ilvesmäki V, Ariel I, Rachmilewitz J, de Groot $\mathrm{N}$ and Hochberg A: Parallel regulation of parentally imprinted H19 and insulin-like growth factor-II genes in cultured human fetal adrenal cells. Endocrinology 134: 2051-2056, 1994. PMID: 7512497. DOI: 10.1210/endo.134.5.7512497

90 Lustig O, Ariel I, Ilan J, Lev-Lehman E, De-Groot N and Hochberg A: Expression of the imprinted gene H19 in the human fetus. Mol Reprod Dev 38: 239-246, 1994. PMID: 7917273. DOI: $10.1002 / \mathrm{mrd} .1080380302$

91 Liu J, Kahri AI, Heikkilä P, Ilvesmäki V and Voutilainen R: H19 and insulin-like growth factor-II gene expression in adrenal tumors and cultured adrenal cells. J Clin Endocrinol Metab 80: 492-496, 1995. PMID: 7531713. DOI: 10.1210/ jcem.80.2.7531713

92 Gao ZH, Suppola S, Liu J, Heikkilä P, Jänne J and Voutilainen R: Association of $\mathrm{H} 19$ promoter methylation with the expression of H19 and IGF-II genes in adrenocortical tumors. J Clin Endocrinol Metab 87: 1170-1176, 2002. PMID: 11889182. DOI: $10.1210 /$ jcem.87.3.8331

93 Glover AR, Zhao JT, Ip JC, Lee JC, Robinson BG, Gill AJ, Soon PS and Sidhu SB: Long noncoding RNA profiles of adrenocortical cancer can be used to predict recurrence. Endocr Relat Cancer 22: 99-109, 2015. PMID: 25595289. DOI: 10.1530/ERC-14-0457

94 Liu J, Kahri AI, Heikkilä P and Voutilainen R: Ribonucleic acid expression of the clustered imprinted genes, p57KIP2, insulinlike growth factor II, and H19, in adrenal tumors and cultured adrenal cells. J Clin Endocrinol Metab 82: 1766-1771, 1997. PMID: 9177379. DOI: 10.1210/jcem.82.6.3968

95 Barreau O, Assié G, Wilmot-Roussel H, Ragazzon B, Baudry C, Perlemoine K, René -Corail F, Bertagna X, Dousset B, Hamzaoui N, Tissier F, de Reynies A and Bertherat J: Identification of a $\mathrm{CpG}$ island methylator phenotype in adrenocortical carcinomas. J Clin Endocrinol Metab 98: E174184, 2013. PMID: 23093492. DOI: 10.1210/jc.2012-2993

96 Creemers SG, van Koetsveld PM, van Kemenade FJ, Papathomas TG, Franssen GJ, Dogan F, Eekhoff EM, van der Valk P, de Herder WW, Janssen JA, Feelders RA and Hofland LJ: Methylation of IGF2 regulatory regions to diagnose adrenocortical carcinomas. Endocr Relat Cancer 23: 727-737, 2016. PMID: 27535174. DOI: 10.1530/ERC-16-0266

97 Miura K, Obama M, Yun K, Masuzaki H, Ikeda Y, Yoshimura S, Akashi T, Niikawa N, Ishimaru T and Jinno Y: Methylation imprinting of H19 and SNRPN genes in human benign ovarian 
teratomas. Am J Hum Genet 65: 1359-1367, 1999. PMID: 10521301. DOI: $10.1086 / 302615$

98 Sievers S, Alemazkour K, Zahn S, Perlman EJ, Gillis AJ, Looijenga LH, Göbel $U$ and Schneider DT: IGF2/H19 imprinting analysis of human germ cell tumors (GCTs) using the methylation-sensitive single-nucleotide primer extension method reflects the origin of GCTs in different stages of primordial germ cell development. Genes Chromosomes Cancer 44: 256-264, 2005. PMID: 16001432. DOI: 10.1002/gcc.20237

99 Kawakami T, Zhang C, Okada Y and Okamoto K: Erasure of methylation imprint at the promoter and CTCF-binding site upstream of $\mathrm{H} 19$ in human testicular germ cell tumors of adolescents indicate their fetal germ cell origin. Oncogene 25: 3225-3236, 2006. PMID: 16434968. DOI: 10.1038/sj.onc.1209362

100 Ji M, Yao Y, Liu A, Shi L, Chen D, Tang L, Yang G, Liang X, Peng $\mathrm{J}$ and Shao C: lncRNA H19 binds VGF and promotes pNEN progression via PI3K/AKT/CREB signaling. Endocr Relat Cancer 26: 643-658, 2019. PMID: 31117050. DOI: 10.1530/ERC-18-0552
101 Ramnarine VR, Alshalalfa M, Mo F, Nabavi N, Erho N, Takhar M, Shukin R, Brahmbhatt S, Gawronski A, Kobelev M, Nouri M, Lin D, Tsai H, Lotan TL, Karnes RJ, Rubin MA, Zoubeidi A, Gleave ME, Sahinalp C, Wyatt AW, Volik S V, Beltran H, Davicioni E, Wang Y and Collins CC: The long noncoding RNA landscape of neuroendocrine prostate cancer and its clinical implications. Gigascience 7: giy050, 2018. PMID: 29757368. DOI: 10.1093/gigascience/giy050

Received December 21, 2020

Revised January 8, 2021 Accepted January 11, 2021 